\title{
Position-dependent radiocarbon content of the macroalgae Undaria pinnatifida as an indicator of oceanographic conditions during algal growth
}

\author{
Naomi Satoh ${ }^{1} \cdot$ Hideki Fukuda $^{1} \cdot$ Yosuke Miyairi $^{1} \cdot$ Yusuke Yokoyama $^{1} \cdot$ Toshi Nagata $^{1}$
}

Received: 19 November 2018 / Revised: 12 February 2019 / Accepted: 2 March 2019 / Published online: 23 March 2019

(c) The Author(s) 2019

\begin{abstract}
The radiocarbon content $\left(\Delta^{14} \mathrm{C}\right)$ of the large brown macroalga Undaria pinnatifida was investigated as an indicator of oceanographic conditions during algal growth in Otsuchi Bay on the Pacific coast of northeastern Japan. In this region, warm boundary currents characterized by high dissolved inorganic carbon (DIC) $\Delta{ }^{14} \mathrm{C}$ and cold subarctic Oyashio Current (low $\Delta{ }^{14} \mathrm{C}$-DIC) flow into the bay seasonally. We hypothesized that $\Delta{ }^{14} \mathrm{C}$ values in $U$. pinnatifida pinnae (leaflet-like structures arising sequentially along the vertical axis of the blade) reflect $\Delta{ }^{14} \mathrm{C}$-DIC values in bay water during photosynthetic production. During the U. pinnatifida cultivation period (November 2013-April 2014), the Oyashio intrusion occurred from early March to early April, accompanied by a decrease in bay water $\Delta^{14} \mathrm{C}$-DIC, from $15.7 \pm 8.6 \%$ o to $-57.1 \pm 20.7 \%$. The $\Delta^{14} \mathrm{C}$ of the pinnae reflected $\Delta{ }^{14} \mathrm{C}$-DIC, as pinnae that formed in early March had significantly higher $\Delta{ }^{14} \mathrm{C}(3.0 \pm 5.4 \% 0)$ than those that formed in early April $\left(-23.6 \pm 7.5 \%\right.$ ). These results indicate that the $\Delta{ }^{14} \mathrm{C}$ of $U$. pinnatifida pinnae can serve as a record of Oyashio intrusion into the bay during algal growth.
\end{abstract}

Keywords Brown macroalgae $\cdot$ Undaria pinnatifida $\cdot$ Ocean current $\cdot$ Oyashio $\cdot$ Radiocarbon $\cdot$ Sanriku coast

\section{Introduction}

The radiocarbon content $\left(\Delta^{14} \mathrm{C}\right)$ of dissolved inorganic carbon (DIC) in surface seawater is influenced by upwelling because there is less ${ }^{14} \mathrm{C}$ in deeper water than in surface water (Key 2001). For example, in the coastal upwelling region of California, there was a decrease in $\Delta^{14} \mathrm{C}$-DIC from 42 to $26 \%$ o during active upwelling in 2006 (Santos et al. 2011). $\Delta{ }^{14} \mathrm{C}$ signals during upwelling are transferred to biogenic carbonates present in hard tissues such as bivalve shells, thus providing a temporal record of the strength of upwelling (Douka et al. 2010; Santos et al. 2011; Ferguson et al. 2013). Because DIC is fixed by photosynthesis, the soft tissues of primary producers such as macroalgae might also reflect the $\Delta^{14} \mathrm{C}$-DIC of upwelled waters and serve as an indicator of oceanic conditions during their growth. Such

Toshi Nagata

nagata@aori.u-tokyo.ac.jp

1 Atmosphere and Ocean Research Institute, The University of Tokyo, 5-1-5, Kashiwanoha, Kashiwa-shi, Chiba 277-8564, Japan information could be useful for assessing the influence of oceanic conditions (upwelling strength and current regimes) on macroalgal growth and distribution. However, to the best of our knowledge, no previous studies have examined whether the $\Delta^{14} \mathrm{C}$ of macroalgal tissues record changes in $\Delta{ }^{14} \mathrm{C}$-DIC in the surrounding seawater during their growth.

In this study, we examined the $\Delta^{14} \mathrm{C}$ of the large brown macroalga Undaria pinnatifida (Laminariales) growing in an embayment of Otsuchi Bay on the Sanriku coast of northeastern Japan (Fig. 1a). Undaria pinnatifida is extensively cultivated in this region, and previous studies have examined the nutrient sources, photosynthetic rates, and other physiological parameters of this kelp species (e.g., Yoshikawa et al. 2001; Carvalho et al. 2009; Gao et al. 2013b; Endo et al. 2017, 2018). The current system comprises the Kuroshio subtropical western boundary current, the Tsugaru Warm Current, and the subarctic cold Oyashio Current (Hanawa and Mitsudera 1987; Shimizu et al. 2001; Oguma et al. 2002; Ishizu et al. 2017). Because the Oyashio Current originates from high latitudes of the North Pacific, where ${ }^{14} \mathrm{C}$-depleted deep water is upwelled, Oyashio waters have substantially less ${ }^{14} \mathrm{C}\left(\Delta^{14} \mathrm{C}\right.$-DIC: -60 to $-10 \%$ ) than the Tsugaru Warm Current waters and Kuroshio waters $\left(\Delta^{14} \mathrm{C}\right.$-DIC: $\left.20-40 \%\right)$; 
Fig. 1 a Undaria pinnatifida cultivation sites (Sts. A2, A3, and A7) in Otsuchi Bay. b Sampling stations for seawater DIC in the offshore region of the Sanriku coast

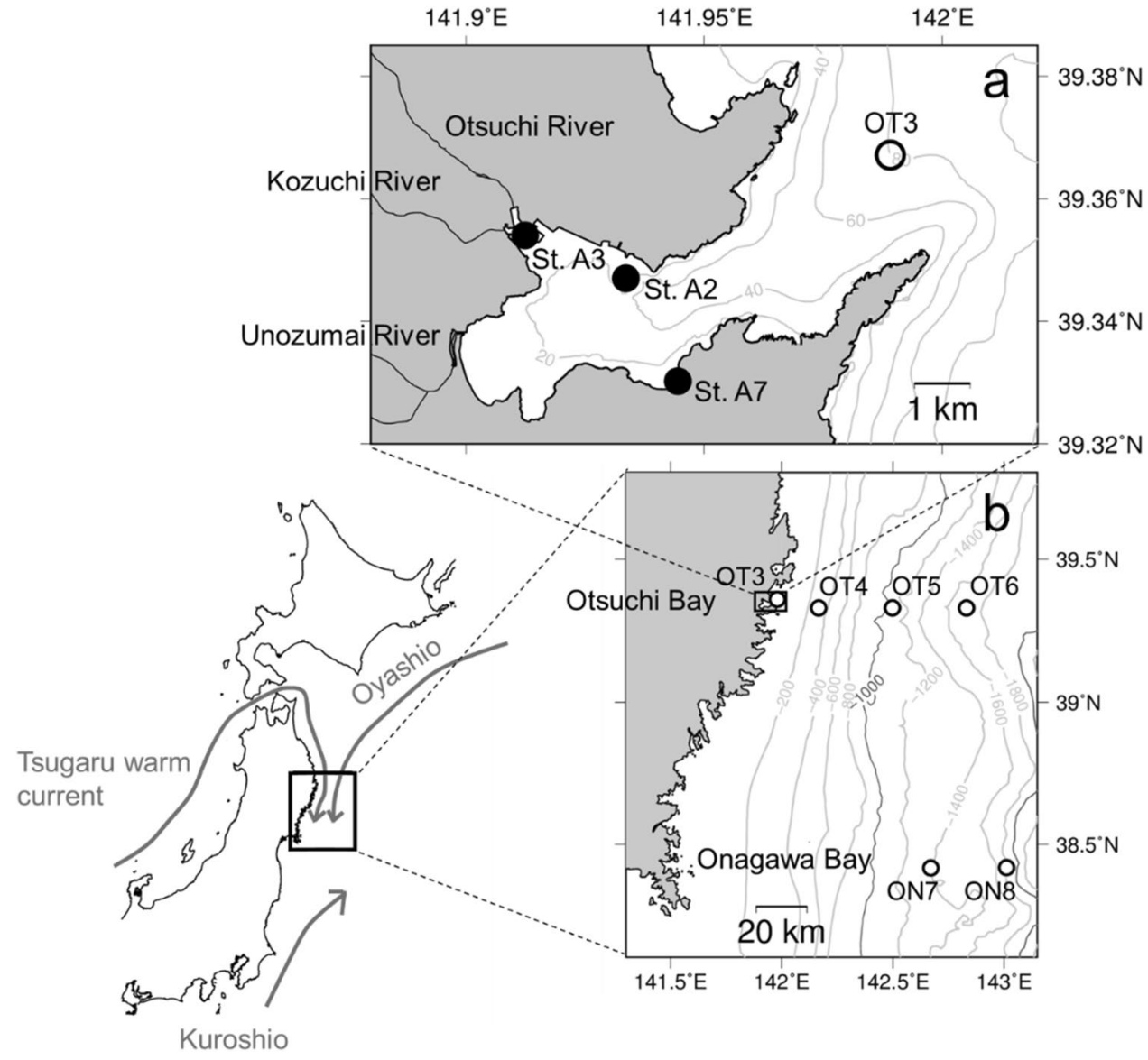

in the latter, $\Delta{ }^{14} \mathrm{C}$-DIC is strongly influenced by the uptake of ${ }^{14} \mathrm{C}$ derived from atmospheric nuclear bomb testing in the 1970s (Key 2001; Kumamoto et al. 2002; Key et al. 2004; $\mathrm{Ge}$ et al. 2016). Undaria pinatifida sporophytes grow rapidly in winter (Yoshikawa et al. 2001), when the prevailing oceanic current changes from the warm current to the Oyashio Current (Ishizu et al. 2017). New pinnae (leaflet-like structures) on sporophytes are synthesized near the meristem, which is located near the bottom of the thallus (Fig. 2). As the thallus grows, it expands upwards and a pair of new pinnae form below the older ones. Thus, the positions of pinnae along the major axis of the thallus represent the pinna formation chronology.

In this study, we tested the hypothesis that the $\Delta^{14} \mathrm{C}$ of $U$. pinnatifida pinnae reflects the $\Delta^{14} \mathrm{C}$-DIC in bay water during photosynthetic production by each pinna. To test this hypothesis, $U$. pinnatifida seedlings were outplanted in Otsuchi Bay, and the $\Delta^{14} \mathrm{C}$ variability at different pinna
Fig. 2 a Undaria pinnatifida sporophyte. New pinnae emerge near the meristem, and their positions along the long axis of the blade reflect the chronological order of their formation. $\mathbf{b}$ The position of pinna $\mathrm{A}\left(L_{\mathrm{a}}\right)$ was defined as the distance $(\mathrm{cm})$ from the punch hole to the base of pinna A after normalization (see Sect. 2)

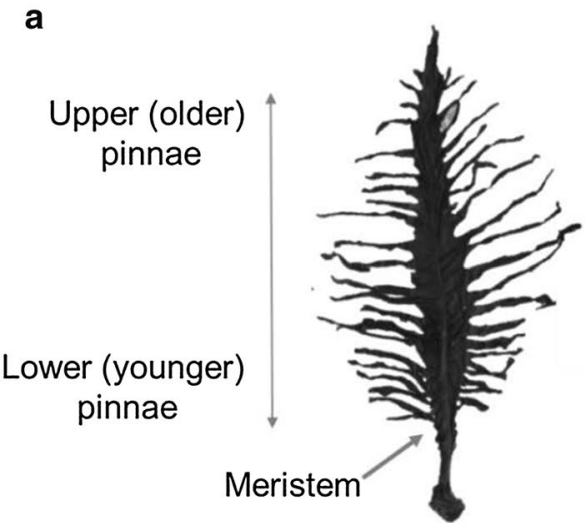

b

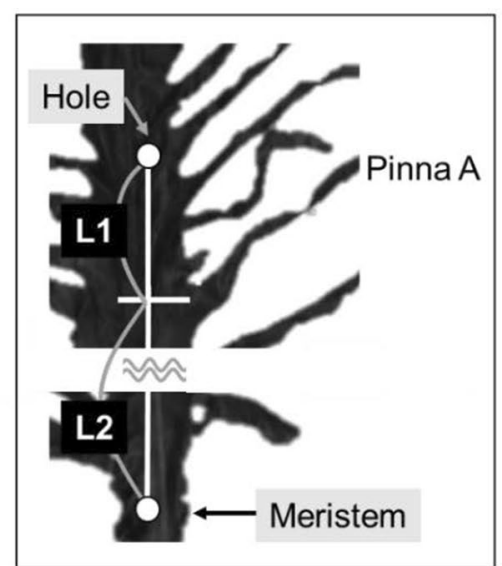


positions was examined in relation to temporal changes in bay water salinity, temperature, and $\Delta^{14} \mathrm{C}$-DIC levels.

\section{Materials and methods}

\subsection{Study site}

Undaria pinnatifida cultivation was conducted in Otsuchi Bay (length: $8 \mathrm{~km}$, width: 2-4 km, depth 9-60 m), a semiclosed bay open to the northwest Pacific Ocean. Oceanic conditions in the bay are related to the coastal ocean outside of the bay due to rapid water exchange between the bay and open ocean (Otobe et al. 2009; Ishizu et al. 2017; Tanaka et al. 2017). Between October and February, the bay water is generally under the influence of the Tsugaru Warm Current, and the intrusion of Oyashio water occurs between February and April (Ishizu et al. 2017; Tanaka et al. 2017). Three rivers (the Otsuchi, Kozuchi, and Unozumai) flow into the bay with a total discharge of $3-35 \mathrm{~m}^{3} \mathrm{~s}^{-1}$ (Ando et al. 2005).

\subsection{Outplanting and sampling of $U$. pinnatifida}

Sporophyte seedlings were obtained from a local fisherman (the general method used for the preparation of sporophyte seedlings was described in Endo et al. 2017) and were outplanted on November 21, 2013, at three stations in Otsuchi Bay (Fig. 1a). At each station, sporophytes $(>2 \mathrm{~cm})$ were attached to a seeded string that was wrapped around a vertical cultivation rope and suspended at a depth of 1-3 m (Yoshikawa et al. 2001). A temperature-salinity logger (Infinity-CTW; JFE Advantech Co, Ltd., Japan) was attached to the line at a depth of approximately $3 \mathrm{~m}$ to collect seawater temperature and salinity data every $10 \mathrm{~min}$. On March 3, 2014, a hole (diameter: $5 \mathrm{~mm}$ ) was punched into the thallus near the meristematic region as a marker of sporophyte growth (Mann 1973; Yoshikawa et al. 2001; Fig. 2b). Undaria pinnatifida individuals (thallus length: 105-175 cm) were harvested on April 8, 2014 (138 days after outplanting) at stations (Sts.) A2 $(n=2), \mathrm{A} 3(n=3)$, and A7 $(n=3)$ (individual codes are listed in Table 1$)$. We conducted transect sampling for $\Delta{ }^{14} \mathrm{C}$ analyses in four haphazardly selected individuals (S1, 3, 4, and 6), on 13-20 pinnae positioned between the hole (upper pinnae) and meristem (lower pinnae) (Fig. 2). In four additional individuals (S2, 5, 7, 8), we conducted two-point sampling, removing only pinnae positioned near the punch hole and near the meristem. Sampling was conducted by removing the top $5 \mathrm{~cm}$ of the pinnae (width: ca. $2 \mathrm{~cm}$, length: 5-30 cm) using scissors.
Table 1 Summary of codes for the individual Undaria pinnatifida samples, sampling stations, and sampling methods

\begin{tabular}{lll}
\hline Individual code & Station & Sampling method \\
\hline S1 & A2 & Transect \\
S2 & A2 & Two-point \\
S3 & A3 & Transect \\
S4 & A3 & Transect \\
S5 & A3 & Two-point \\
S6 & A7 & Transect \\
S7 & A7 & Two-point \\
S8 & A7 & Two-point \\
\hline
\end{tabular}

Pinna position $(\mathrm{cm})$ was defined as the distance from the hole to the base of the pinna after normalization to correct for differences in blade length among individuals (Fig. 2b). Normalization was conducted according to the following equation:

$L_{\mathrm{a}}=\frac{L_{1}}{L_{1}+L_{2}} \times M$,

where $L_{1}$ is the distance $(\mathrm{cm})$ between the punch hole and the base of pinna A, $L_{2}$ is the distance $(\mathrm{cm})$ between the meristem and the base of pinna $\mathrm{A}$, and the $M$ is the average value of $L_{1}+L_{2}$ for four individuals (mean and standard deviation: $66.2 \pm 8.6 \mathrm{~cm})$.

\subsection{Seawater and river water sampling to determine DIC concentration and $\Delta{ }^{14} C$-DIC}

Seawater samples were collected in Otsuchi Bay at depths of 1 and $3 \mathrm{~m}$ on January 21, March 3, and April 8, 2014. River water samples were collected at the mouths of the Otsuchi, Kozuchi, and Unozumai rivers where they flowed into the bay (Fig. 1a) on January 22, March 3, and April 12,2014 . To examine the water mass distribution along the Snariku coast during the study period, we also collected offshore water using the R/V Shinsei-Maru on March 16 and 17, 2014, along transects from river mouths to offshore of Otsuchi Bay (OT3-6) and offshore of Onagawa Bay (south of Otsuchi Bay, ON7 and ON8) (Fig. 1b). Samples were collected from 2-6 depths at each station.

River water samples were collected using a plastic bucket and stored in $500 \mathrm{~mL}$ glass bottles with plastic caps. Seawater (bay and offshore) samples were collected using 12-L or 5-L Niskin bottles, except that a plastic bucket was used to collect surface water. Seawater samples were stored in $100 \mathrm{~mL}$ glass vials with rubber stoppers. River and seawater samples were preserved with $\mathrm{HgCl}_{2}$; 
a saturated aqueous solution of $\mathrm{HgCl}_{2}$ was added to the sample at a volumetric ratio $\left(\mathrm{HgCl}_{2}\right.$ :sample) of 1:1000.

\subsection{Chemical analyses}

Macroalgal samples were acidified overnight by fumigating with $\mathrm{HCl}$ in centrifugation tubes to remove inorganic carbon. After removing excess $\mathrm{HCl}$ using a vacuum desiccator, dried samples were combusted in evacuated quartz tubes containing copper oxide and Sulfix for $30 \mathrm{~min}$ at $500{ }^{\circ} \mathrm{C}$, followed by oxidation to $\mathrm{CO}_{2}$ for $2 \mathrm{~h}$ at $850^{\circ} \mathrm{C}$. Then $\mathrm{CO}_{2}$ was purified in a vacuum line for graphitization. Seawater $(230 \mathrm{~mL})$ or river water $(570 \mathrm{~mL})$ samples were acidified by adding $85 \% \mathrm{H}_{3} \mathrm{PO}_{4}$ and bubbled with helium (ultrahigh-purity grade) for $15 \mathrm{~min}$ to strip $\mathrm{CO}_{2}$ from the water (McNichol et al. 1994). Extracted $\mathrm{CO}_{2}$ was purified in the vacuum line and reduced to graphite powder following the method of Yokoyama et al. (2007). The DIC concentrations of seawater and river water were calculated from the pressure of $\mathrm{CO}_{2}$ gas extracted from the vacuum line for the graphitization (McNichol et al. 1994).

We determined $\Delta{ }^{14} \mathrm{C}$ using a single-stage accelerator mass spectrometer (National Electrostatics Corporation, USA) at the University of Tokyo Atmosphere and Ocean Research Institute (Yokoyama et al. 2019). The $\Delta{ }^{14} \mathrm{C}$ values are reported as sample ${ }^{14} \mathrm{C} /{ }^{12} \mathrm{C} \%$ deviations relative to the 95\% Oxalic Acid-1 standard following the conventional standardization procedure to correct for isotope fractionation and ${ }^{14} \mathrm{C}$ decay (Stuiver and Polach 1977). The analytical precision $(1 \sigma)$ of the measurements ranged from 0.3 to $0.8 \%$.

\subsection{Statistical analyses}

Statistical analyses of $\Delta{ }^{14} \mathrm{C}$ data were conducted using Student's $t$ test or two-way analysis of variance (ANOVA) at a level of $p<0.05$ after confirming that the data met the normality (Shapiro-Wilk test) and equal variance (Bartlett test) assumptions. When these assumptions were not fulfilled, nonparametric tests (the Kruskal-Wallis test followed by the Steel-Dwass multiple comparison test or Spearman's rank correlation analysis) were conducted. All statistical analyses were performed using R v.3.3.2 (R Development Core Team 2016).
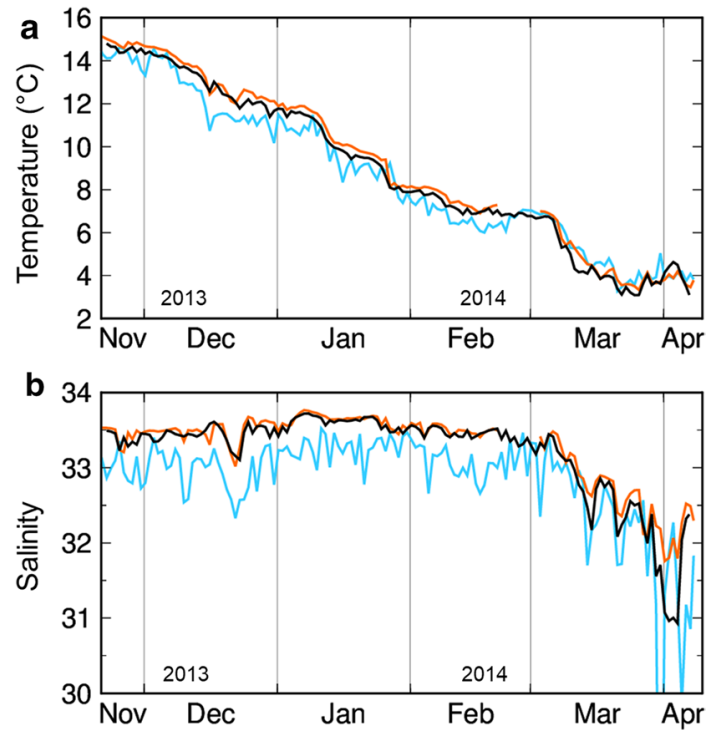

Fig. 3 Time series of daily average $\mathbf{a}$ temperature and $\mathbf{b}$ salinity at the cultivation sites (depth: $3 \mathrm{~m}$ ) from November 21 to April 8. Data collected at Sts. A2, A3, and A7 are indicated by black, orange, and blue lines, respectively

\section{Results}

\subsection{Temporal variation in salinity and temperature in the bay}

In Otsuchi Bay, seawater temperature gradually decreased from late November $\left(15^{\circ} \mathrm{C}\right)$ to early March $\left(6.7{ }^{\circ} \mathrm{C}\right)$ (Fig. 3a). At Sts. A2 and A3, salinity did not significantly change between November 22 and March 5, with an average value of $33.5 \pm 0.13$. Salinity markedly decreased from March 6 to early April, accompanied by a decrease in temperature (Fig. 3b). At St. A7, general trends in seasonal salinity and temperature were similar to those at other stations, except for the presence of short-term (timescale of a few days) fluctuations in salinity and temperature (Fig. 3a, b). Both temperature and salinity were generally lower at St. A7 than at Sts. A2 and A3 (Fig. 3a, b).

\section{2 $\Delta^{14} C$-DIC and DIC concentrations in bay and river water}

In bay water, the mean $\Delta{ }^{14} \mathrm{C}$-DIC values were $17.5 \% \circ \pm 6.1 \% \circ$ and $15.7 \% \circ \pm 8.6 \%$ on January 21 and March 3, respectively, and differences between the values obtained for those dates were not significant $(p>0.05)$ (Table 2). The mean $\Delta{ }^{14} \mathrm{C}$-DIC of seawater on April $8(-57.1 \% \circ \pm-20.7 \%$ ) was significantly lower than the corresponding values on January 21 and March 3 $\left(p<0.05\right.$, Table 2). The $\Delta{ }^{14} \mathrm{C}$-DIC offset between March 
Table 2 Dissolved inorganic radiocarbon contents $\left(\Delta^{14} \mathrm{C}\right.$-DIC) and dissolved inorganic carbon (DIC) concentrations in bay water collected at depths of 1 and $3 \mathrm{~m}$ at stations (Sts.) A2, A3, and A7 ( $n=6$ except for the DIC concentration on March 3, when one sample was lost)

\begin{tabular}{|c|c|c|c|c|}
\hline \multirow[t]{2}{*}{ Date } & \multicolumn{3}{|c|}{$\Delta^{14} \mathrm{C}-\mathrm{DIC}(\% \circ)$} & \multirow{2}{*}{$\begin{array}{l}\text { DIC concen- } \\
\text { tration }(\mathrm{mM}) \\
\text { Mean } \pm \mathrm{SD}\end{array}$} \\
\hline & Min. & Max. & Mean \pm SD & \\
\hline Jan 21, 2014 & 5.7 & 23.2 & $17.5 \pm 6.1 \mathrm{a}$ & $1.97 \pm 0.12$ \\
\hline Mar 3, 2014 & 2.6 & 26.8 & $15.7 \pm 8.6 \mathrm{a}$ & $1.92 \pm 0.03$ \\
\hline Apr 8, 2014 & -85.2 & -30.4 & $-57.1 \pm 20.7 b$ & $1.94 \pm 0.05$ \\
\hline
\end{tabular}

Mean $\Delta^{14} \mathrm{C}$-DIC values with different appended letters are significantly different $(p<0.05$, Kruskal-Wallis test followed by SteelDwass test)

$S D$ standard deviation

Table $3 \quad \Delta^{14} \mathrm{C}$-DIC and DIC concentrations in river water

\begin{tabular}{llcl}
\hline River & Date & $\Delta^{14}$ C-DIC (\%o) & $\begin{array}{l}\text { DIC concen- } \\
\text { tration }(\mathrm{mM})\end{array}$ \\
\hline Otsuchi & Jan 22, 2014 & $-10.1 \pm 2.9$ & 0.53 \\
& Mar 3, 2014 & $-18.0 \pm 2.9$ & 0.50 \\
& Apr 12, 2014 & $-21.8 \pm 2.9$ & 0.45 \\
Kozuchi & Jan 22, 2014 & $-3.1 \pm 2.9$ & 0.42 \\
& Mar 3, 2014 & $-35.3 \pm 3.0$ & 0.40 \\
& Apr 12, 2014 & $-2.8 \pm 4.0$ & 0.33 \\
Unozumai & Jan 22, 2014 & $1.3 \pm 3.0$ & 0.44 \\
& Mar 3, 2014 & $8.9 \pm 2.9$ & 0.47 \\
& Apr 12, 2014 & $1.4 \pm 4.1$ & 0.41 \\
\hline
\end{tabular}

Errors for $\Delta{ }^{14} \mathrm{C}$ indicate the analytical precision $(1 \sigma)$

3 and April 8 was $72.8 \%$. The DIC concentration in bay water was in the range 1.92-1.97 $\mathrm{mM}$, changing little over time (Table 2). The $\Delta{ }^{14} \mathrm{C}$-DIC and DIC concentrations in river water ranged from -35.3 to $8.9 \%$ and from 0.33 to $0.53 \mathrm{mM}$, respectively (Table 3 ).

\subsection{Temperature, salinity, and $\Delta^{14} \mathrm{C}$-DIC in offshore waters}

In seawater off Otsuchi Bay (OT Sts. OT3-5), a cold $\left(1.5-4.1^{\circ} \mathrm{C}\right)$ and low-saline $(32.7-33.5)$ water mass prevailed at depths of $0-200 \mathrm{~m}$. Warmer $\left(7.0-8.1^{\circ} \mathrm{C}\right)$ and saltier (33.5-33.7) waters were prevalent in the region approximately $60 \mathrm{~km}$ south of the OT stations (off Onagawa Bay, Sts. ON7-8; Fig. 4a, b, Table 4). Values of $\Delta^{14} \mathrm{C}-\mathrm{DIC}$ in the upper water column (depth: 0-200 m) of the OT stations ranged from -73.7 to $-10.0 \%$, whereas corresponding values for seawater collected at $\mathrm{ON}$ stations were higher, ranging from -9.6 to $8.1 \%$ (Fig. $4 \mathrm{c}$, Table 4 ). The $\Delta^{14} \mathrm{C}$-DIC values of seawater collected at a depth of $1000 \mathrm{~m}$ ranged from -192 to $-199 \%$ o (Table 4 ).

\section{$3.4 \Delta{ }^{14} \mathrm{C}$ of $U$. pinnatifida pinnae}

Data collected using the transect and two-point sampling methods were used to obtain mean $\Delta{ }^{14} \mathrm{C}$ values for upper (old) and lower (young) U. pinnatifida pinnae. Depending on the station, mean $\Delta{ }^{14} \mathrm{C}$ values of the upper and lower pinnae ranged from 1.2 to $5.9 \%$ and from -25.4 to $-21.2 \%$, respectively (Table 5). To examine the significance of the differences in $\Delta^{14} \mathrm{C}$ values among stations and between positions, two-way ANOVA was conducted using station and position as two fixed factors. The results showed that $\Delta{ }^{14} \mathrm{C}$ values differed significantly $(p<0.05)$ between positions (upper versus lower pinnae), whereas the difference among stations (A2, A3, and A7) was insignificant $(p>0.05)$. For the pooled data, the mean $\Delta{ }^{14} \mathrm{C}$ of the upper pinnae (mean \pm SD: $3.0 \pm 5.4 \%$ ) was significantly lower than that of the lower pinnae $(-23.6 \pm 7.5 \%$ ), with an offset value of 26.6\% ( $p<0.0001$, Student's $t$ test) (Table 5; Fig. 5).
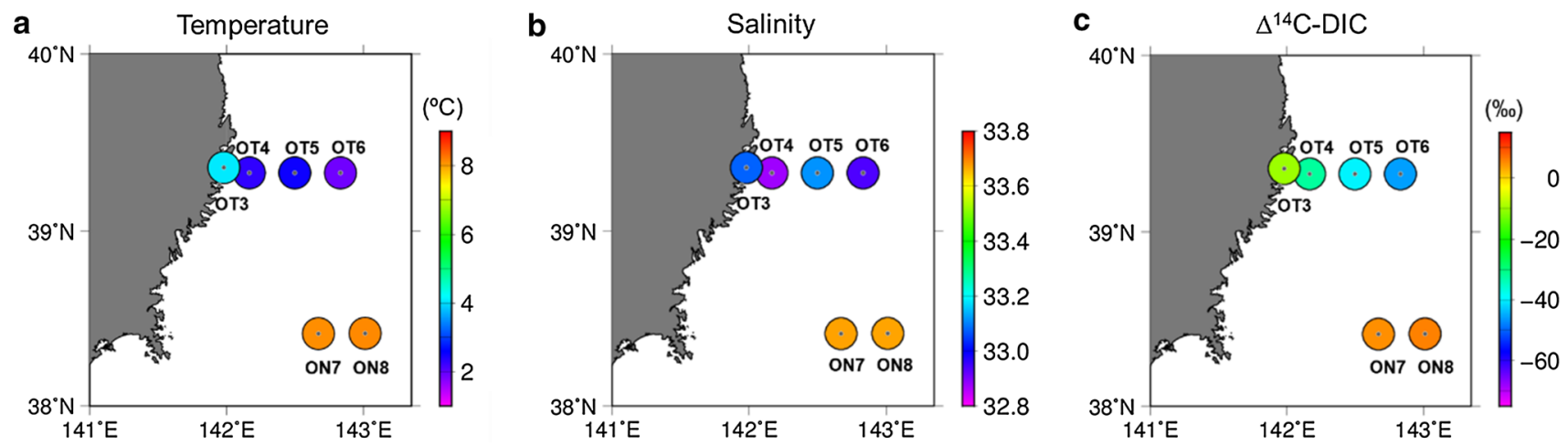

Fig. 4 Spatial distributions of a temperature, b salinity, and c $\Delta{ }^{14} \mathrm{C}$-DIC collected off the Sanriku coast on March 16-17. Data shown were collected at depths of 50 and $60 \mathrm{~m}$ 
Table 4 Temperature, salinity, and $\Delta^{14} \mathrm{C}$-DIC in the offshore region (see Fig. 1b for sampling locations)

\begin{tabular}{|c|c|c|c|c|c|c|}
\hline Station & Position & Date & Depth (m) & Temp. $\left({ }^{\circ} \mathrm{C}\right)$ & Salinity & $\Delta^{14} \mathrm{C}(\% \circ)$ \\
\hline \multirow[t]{2}{*}{ OT3 } & \multirow{2}{*}{$\begin{array}{l}39^{\circ} 22^{\prime} 00^{\prime \prime} \mathrm{N} \\
141^{\circ} 59^{\prime} 21^{\prime \prime} \mathrm{E}\end{array}$} & \multirow[t]{2}{*}{16 Mar 2014} & 20 & 3.02 & 32.86 & $-22.0 \pm 3.9$ \\
\hline & & & 60 & 4.05 & 33.07 & $-10.0 \pm 3.3$ \\
\hline \multirow[t]{5}{*}{ OT4 } & \multirow{5}{*}{$\begin{array}{l}39^{\circ} 20^{\prime} 20^{\prime \prime} \mathrm{N} \\
142^{\circ} 10^{\prime} 38^{\prime \prime} \mathrm{E}\end{array}$} & \multirow[t]{5}{*}{17 Mar 2014} & 0 & 2.08 & 32.75 & $-36.5 \pm 5.2$ \\
\hline & & & 20 & 2.10 & 32.77 & $-27.9 \pm 5.7$ \\
\hline & & & 50 & 2.30 & 32.88 & $-32.0 \pm 5.3$ \\
\hline & & & 100 & 2.95 & 33.17 & $-35.2 \pm 5.2$ \\
\hline & & & 276 & 2.70 & 33.44 & $-69.2 \pm 5.9$ \\
\hline \multirow[t]{6}{*}{ OT5 } & \multirow{6}{*}{$\begin{array}{l}39^{\circ} 20^{\prime} 21^{\prime \prime} \mathrm{N} \\
142^{\circ} 30^{\prime} 30^{\prime \prime} \mathrm{E}\end{array}$} & \multirow[t]{6}{*}{17 Mar 2014} & 0 & 1.47 & 32.82 & $-36.0 \pm 4.8$ \\
\hline & & & 20 & 1.54 & 32.85 & $-35.8 \pm 5.4$ \\
\hline & & & 50 & 2.52 & 33.12 & $-39.8 \pm 5.2$ \\
\hline & & & 100 & 3.37 & 33.26 & $-31.2 \pm 4.9$ \\
\hline & & & 200 & 2.83 & 33.45 & $-66.9 \pm 5.2$ \\
\hline & & & 1014 & 3.05 & 34.33 & $-199.2 \pm 2.9$ \\
\hline \multirow[t]{6}{*}{ OT6 } & \multirow{6}{*}{$\begin{array}{l}39^{\circ} 20^{\prime} 20^{\prime \prime} \mathrm{N} \\
142^{\circ} 50^{\prime} 29^{\prime \prime} \mathrm{E}\end{array}$} & \multirow[t]{6}{*}{17 Mar 2014} & 0 & 2.43 & 32.72 & $-44.3 \pm 3.4$ \\
\hline & & & 20 & 1.59 & 32.74 & $-44.9 \pm 3.2$ \\
\hline & & & 50 & 1.90 & 32.94 & $-45.8 \pm 3.0$ \\
\hline & & & 100 & 2.77 & 33.14 & $-58.2 \pm 2.9$ \\
\hline & & & 200 & 2.37 & 33.41 & $-73.7 \pm 3.3$ \\
\hline & & & 1000 & 2.86 & 34.37 & $-196.2 \pm 2.6$ \\
\hline \multirow[t]{5}{*}{ ON7 } & \multirow{5}{*}{$\begin{array}{l}38^{\circ} 25^{\prime} 39^{\prime \prime} \mathrm{N} \\
142^{\circ} 40^{\prime} 25^{\prime \prime} \mathrm{E}\end{array}$} & \multirow[t]{5}{*}{16 Mar 2014} & 0 & 8.11 & 33.67 & $-4.7 \pm 4.0$ \\
\hline & & & 50 & 8.11 & 33.67 & $4.9 \pm 4.1$ \\
\hline & & & 100 & 7.90 & 33.65 & $-9.6 \pm 3.9$ \\
\hline & & & 200 & 7.51 & 33.61 & $4.7 \pm 4.3$ \\
\hline & & & 1000 & 2.94 & 34.41 & $-192.3 \pm 3.8$ \\
\hline \multirow[t]{5}{*}{ ON8 } & \multirow{5}{*}{$\begin{array}{l}38^{\circ} 25^{\prime} 07^{\prime \prime} \mathrm{N} \\
143^{\circ} 01^{\prime} 10^{\prime \prime} \mathrm{E}\end{array}$} & \multirow[t]{5}{*}{16 Mar 2014} & 0 & 8.15 & 33.67 & $8.2 \pm 5.0$ \\
\hline & & & 20 & 8.15 & 33.67 & $1.4 \pm 2.9$ \\
\hline & & & 50 & 8.14 & 33.67 & $5.9 \pm 4.3$ \\
\hline & & & 100 & 7.94 & 33.66 & $0.8 \pm 3.2$ \\
\hline & & & 200 & 6.95 & 33.54 & $0.3 \pm 3.0$ \\
\hline
\end{tabular}

Errors for $\Delta^{14} \mathrm{C}$ indicate the analytical precision $(1 \sigma)$

\begin{tabular}{|c|c|c|c|c|c|c|}
\hline \multirow[t]{3}{*}{ Station } & \multirow[t]{3}{*}{$n$} & \multicolumn{5}{|c|}{$\Delta^{14} \mathrm{C}(\% \circ)$} \\
\hline & & \multicolumn{2}{|c|}{ Upper pinnae } & \multicolumn{2}{|c|}{ Lower pinnae } & \multirow{2}{*}{$\begin{array}{l}\text { Offse } \\
\text { Mean }\end{array}$} \\
\hline & & Mean & SD & Mean & SD & \\
\hline A2 & 2 & 1.2 & 11.2 & -25.4 & 6.1 & 26.6 \\
\hline A3 & 3 & 1.2 & 0.9 & -24.9 & 11.5 & 26.1 \\
\hline A7 & 3 & 5.9 & 4.2 & -21.2 & 1.4 & 27.1 \\
\hline Pooled & 8 & 3.0 & 5.4 & -23.6 & 7.5 & 26.6 \\
\hline
\end{tabular}

Table $5 \quad \Delta^{14} \mathrm{C}$ values in upper and lower pinnae and their offset values at different sampling stations

\section{Discussion}

The most important finding of this study is that the $\Delta^{14} \mathrm{C}$ of pinnae displayed systematic position-dependent variability, with an offset of $26.6 \%$ between pinnae formed in ant for four individuals $\left(r_{\mathrm{s}}=-0.579\right.$ to $\left.-0.863, p<0.05\right)$ and the pooled data $\left(r_{\mathrm{s}}=-0.619, p<0.001\right)$ (Table 6). 


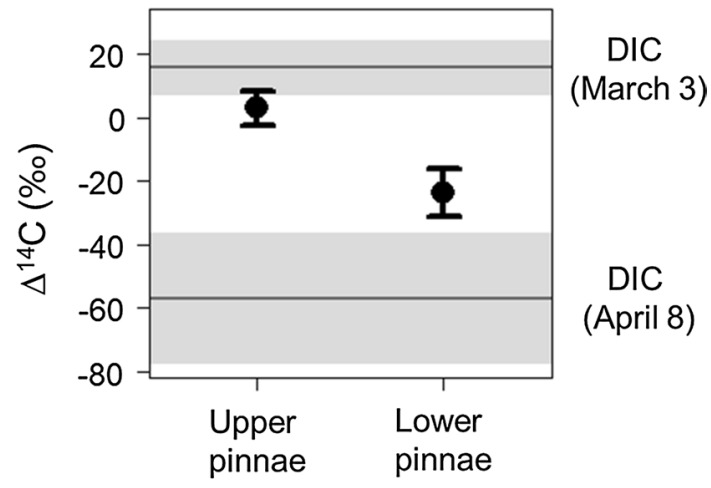

Fig. $5 \Delta^{14} \mathrm{C}$ values for lower (near the punch hole) and upper (near the meristematic region) $U$. pinnatifida pinnae. Solid circles with error bars indicate means and standard deviations of $\Delta^{14} \mathrm{C}$ for upper and lower pinnae $(n=8)$. Gray lines and shaded regions represent means and standard deviations of $\Delta^{14} \mathrm{C}$-DIC values, respectively, for March 3 (when holes were punched) and April 8 (when individuals were harvested)

early March and those formed in early April. We argue that this $\Delta^{14} \mathrm{C}$ shift in $U$. pinnatifida pinnae tissues reflected changes in oceanic current conditions in the bay.

\subsection{Oyashio intrusion and $\Delta^{14}$ C-DIC}

The decreasing trend in salinity and temperature in the bay between March 6 and April 8 was primarily a consequence of the Oyashio intrusion during this period. This assertion is supported by the results of Ishizu et al. (2017) from a time series of mooring and hydrographic observations at the mouth of Otsuchi Bay; a prominent low-salinity event occurred between early March and April, 2014. Satellite imagery showed that cold Oyashio water gradually moved north to south to cover the Sanriku coast north of $39^{\circ} \mathrm{N}$ in early March, including the area outside of Otsuchi Bay (Ishizu et al. 2017). These results indicate that the lowsalinity event was caused by the intrusion of Oyashio water from offshore. Although marked decreases in both salinity and temperature were observed in the current study after March 6 at the three stations, salinity was generally low at St. A7 (south of the bay), with short-term large-amplitude fluctuations. The river plume was directed southward due to the Coriolis force in the Otsuchi Bay, and low-salinity fluctuations at St. A7 appear to have been caused by river discharge (Ishizu et al. 2017).

The substantial decrease in $\Delta{ }^{14} \mathrm{C}$-DIC from $16.6 \%$ (January 21 and March 3) to $-57.1 \%$ (April 8) in the bay can be explained by the gradual mixing of ${ }^{14} \mathrm{C}$-rich seawater of subtropical origin with ${ }^{14} \mathrm{C}$-depleted Oyashio water. Consistent with this notion, our data collected at OT stations during mid-March showed that the ${ }^{14} \mathrm{C}$-depleted water mass ( $\Delta^{14} \mathrm{C}$-DIC: -73.7 to $-10.0 \%$ ) was indeed prevalent in the surface layer (0-200 $\mathrm{m}$ depth) near the mouth of the bay (Fig. 4, Table 4). This water mass was characterized by low temperature $\left(1.5-4.1{ }^{\circ} \mathrm{C}\right)$ and low salinity $(32.7-33.3)$ indicative of Oyashio or Oyashio-influenced coastal Oyashio water according to the Sanriku water mass classification proposed by
Fig. 6 Relationship between normalized pinna position and $\Delta{ }^{14} \mathrm{C}$ for four individuals. See Table 6 for statistical results of the rank correlation between pinna position and $\Delta^{14} \mathrm{C}$
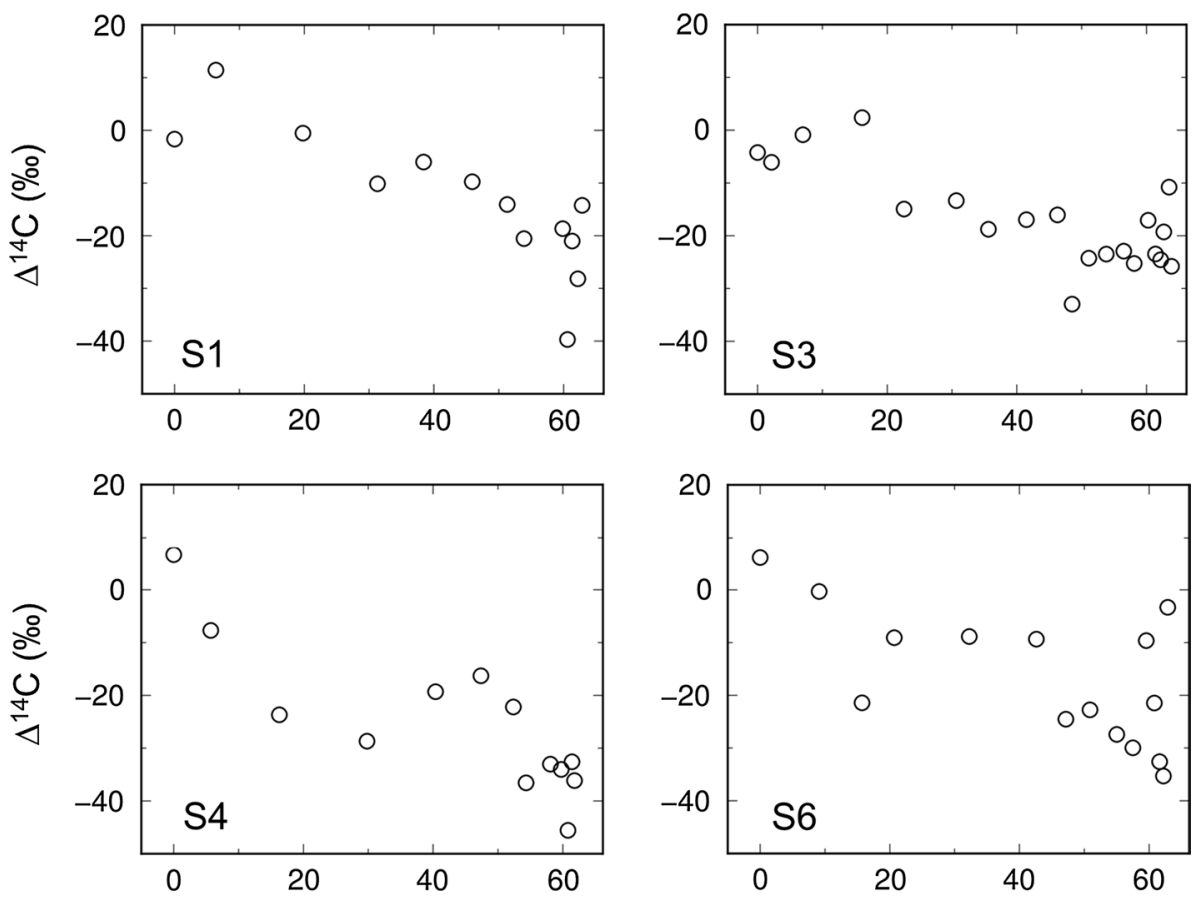

Normalized pinna position (cm) 
Table 6 Spearman's rank correlation $\left(r_{\mathrm{s}}\right)$ between pinna positions and $\Delta^{14} \mathrm{C}$ values

\begin{tabular}{|c|c|c|c|}
\hline \multirow[t]{3}{*}{ Individual code } & \multicolumn{3}{|c|}{ Pinna position } \\
\hline & \multicolumn{3}{|c|}{$\Delta^{14} \mathrm{C}(\% \circ)$} \\
\hline & $r_{\mathrm{s}}$ & $p$ & $n$ \\
\hline S1 & -0.863 & $<0.001$ & 13 \\
\hline S3 & -0.660 & $<0.005$ & 20 \\
\hline S4 & -0.802 & $<0.005$ & 13 \\
\hline S6 & -0.579 & $<0.05$ & 15 \\
\hline Pooled & -0.619 & $<0.001$ & 61 \\
\hline
\end{tabular}

Hanawa and Mitsudera (1987), and therefore may have been a source of the ${ }^{14} \mathrm{C}$-depleted water that intruded into the bay. Values of $\Delta^{14} \mathrm{C}$-DIC were higher at ON stations than at OT stations, suggesting that ${ }^{14} \mathrm{C}$-depleted waters moved from north to south as the Oyashio gradually moved southward after early March in areas offshore the Sanriku coast. The presence of ${ }^{14} \mathrm{C}$-depleted deep water (depth: $1000 \mathrm{~m}$ ) with an estimated radiocarbon age of ca. 2000 years in this region is consistent with the results of previous studies (see $\mathrm{McNichol}$ and $\mathrm{Alu}-$ wihare 2007).

In addition to Oyashio intrusion, the river discharge might have decreased the salinity of the bay water, thereby causing ${ }^{14} \mathrm{C}$ depletion of bay water, as the river DIC was generally depleted in ${ }^{14} \mathrm{C}$ (the lowest $\Delta{ }^{14} \mathrm{C}$-DIC value of $-35.3 \%$ was observed on March 3 at the Kozuchi River; Table 3). To evaluate the maximum potential influence of the river discharge on the $\Delta^{14} \mathrm{C}$-DIC value of bay water, we constructed the following simple two-end-member mass balance model, assuming that the decrease in salinity from March 3 ( $\mathrm{Sal}_{1}$, range 32.3-33.4, Fig. 3) to April 8 ( $\mathrm{Sal}_{2}$, range 31.8-32.4, Fig. 3) was caused solely by river discharge into the bay:

$\Delta^{14} \mathrm{C}^{-\mathrm{DIC}_{\text {mix }}}=\frac{f\left[\mathrm{DIC}_{\mathrm{r}}\right] \Delta^{14} \mathrm{C}-\mathrm{DIC}_{\mathrm{r}}+(1-f)\left[\mathrm{DIC}_{1}\right] \Delta^{14} \mathrm{C}-\mathrm{DIC}_{1}}{\left[\mathrm{DIC}_{\text {mix }}\right]}$.

In this model, $f$ is the maximum potential fraction of river water in the bay water samples collected on April 8, which was calculated using the following equation: $f=\left(\mathrm{Sal}_{1}-\mathrm{Sal}_{2}\right) /\left(\mathrm{Sal}_{1}\right)$ (estimated range of $\left.f: 0.016-0.034\right)$. $\left[\mathrm{DIC}_{\mathrm{r}}\right]$ and $\Delta^{14} \mathrm{C}-\mathrm{DIC}_{\mathrm{r}}$ represent the DIC concentration and $\Delta^{14} \mathrm{C}$-DIC of river water, respectively [to determine these parameters, the maximum DIC concentration of $0.53 \mathrm{mM}$ (Table 3 ) and the lowest $\Delta^{14} \mathrm{C}$-DIC value of $-35.3 \%$ o (Table 3) were used to evaluate the maximum influence of river water on $\Delta^{14} \mathrm{C}$-DIC in the bay]. [DIC ${ }_{1}$ ] and $\Delta^{14} \mathrm{C}-\mathrm{DIC}_{1}$ represent the DIC concentration and $\Delta^{14} \mathrm{C}$-DIC of bay water collected on 3 March, respectively (these parameters were set to $1.92 \mathrm{mM}$ and $15.7 \%$, respectively, based on the data presented in Table 2). [DIC $\mathrm{Dix}_{\text {mix }}$ ] and $\Delta{ }^{14} \mathrm{C}-\mathrm{DIC}_{\text {mix }}$ are the estimated DIC concentration and the estimated $\Delta{ }^{14} \mathrm{C}$-DIC value, respectively, of "virtual" water obtained by mixing the bay water collected on March 3 with river water at a mixing ratio of $f\left(\left[\mathrm{DIC}_{\text {mix }}\right]=f\left[\mathrm{DIC}_{\mathrm{r}}\right]+(1-f)\left[\mathrm{DIC}_{1}\right]\right)$. We estimated that $\Delta^{14} \mathrm{C}-\mathrm{DIC}_{\text {mix }}$ is in the range $15.2-15.5 \%$, with an offset value relative to $\Delta^{14} \mathrm{C}$-DIC $\mathrm{DI}_{1}$ of $0.2-0.5 \%$. This offset value is much smaller than the $\Delta^{14} \mathrm{C}$-DIC offset observed in the bay $(72.8 \%$ ). As the model described above assumed that the decrease in salinity was solely caused by river discharge (thus providing the maximum potential influence of river water on DIC dynamics in the bay), we conclude that river discharge had little effect on temporal variability in bay water $\Delta^{14} \mathrm{C}$-DIC.

\subsection{Oyashio intrusion and $\Delta{ }^{14} \mathrm{C}$ of $U$. pinnatifida}

Undaria pinnatifida pinnae displayed systematic positiondependent variability in $\Delta^{14} \mathrm{C}$, with a tendency for ${ }^{14} \mathrm{C}$ depletion from older to newly formed pinnae. The most likely explanation for this tendency is a shift in the prevailing current from the warm current to the cold Oyashio Current during $U$. pinnatifida growth. On March 3, bay water DIC was relatively enriched in ${ }^{14} \mathrm{C}$, such that the $\Delta^{14} \mathrm{C}$ of upper pinnae was relatively high. As the Oyashio intrusion progressed, bay water DIC became depleted in ${ }^{14} \mathrm{C}$, leading to a decrease in $\Delta{ }^{14} \mathrm{C}$ in the lower pinnae, which were produced in early April. Thus, the $\Delta^{14} \mathrm{C}$ distribution in the pinnae recorded the $\Delta^{14} \mathrm{C}$ shift of ambient DIC associated with changes in the prevailing ocean current.

The $\Delta^{14} \mathrm{C}$ values of macroalgal photosynthates directly reflect the source $\Delta^{14} \mathrm{C}$-DIC signature because $\Delta^{14} \mathrm{C}$, by definition, is corrected for isotope fractionation during carbon assimilation and other metabolic processes using the $\delta^{13} \mathrm{C}$ value (Stuiver and Polach 1977; McNichol and Aluwihare 2007). Therefore, the effects of isotope fractionation can be ignored in the interpretation of $\Delta^{14} \mathrm{C}$ variability in and among organisms. However, $\Delta^{14} \mathrm{C}$ variability among $U$. pinnatifida pinnae should be interpreted with caution because of potential mixing of "old" and "new" photosynthates through metabolic processes. In this study, mean $\Delta{ }^{14} \mathrm{C}$ values in upper pinnae $(3.0 \pm 5.4 \%$ ) were lower than the $\Delta^{14} \mathrm{C}$-DIC value on March $3(15.7 \pm 8.6 \%$, and those in lower pinnae $(-23.6 \pm 7.5 \%$ ) were higher than the $\Delta^{14} \mathrm{C}$-DIC value on April $8(-57.1 \pm 20.7 \%$ ) (Fig. 5). Thus, differences in $\Delta^{14} \mathrm{C}$ values before and after the Oyashio intrusion were greater for DIC than for pinnae. Deviation of the mean $\Delta^{14} \mathrm{C}$ values of pinnae from the corresponding $\Delta^{14} \mathrm{C}$-DIC values and apparent attenuation of the isotopic offset for pinnae relative to DIC could be explained by carbon turnover (Carballeira et al. 2014). Pinnae formed in the warm current (high $\Delta{ }^{14} \mathrm{C}$ ) were later exposed to the cold current (low $\Delta^{14} \mathrm{C}$ ), which may have resulted in the mixing of preexisting carbon (high $\Delta{ }^{14} \mathrm{C}$ ) 
and newly formed carbon (low $\Delta{ }^{14} \mathrm{C}$ ) within a single pinna. Although carbon that is newly fixed by older pinnae is translocated to the meristem to support the formation of younger pinnae (Wu and Meng 1997), the mixing of old and new carbon can still occur due to tissue carbon turnover. For a quantitative assessment of the contributions of different currents to the supply of DIC for pinnae synthesis, the effect of carbon turnover on the $\Delta^{14} \mathrm{C}$ signature of pinnae must be evaluated in future research.

It is also important to consider the timescale of blade growth. Undaria pinnatifida pinnae elongate from the base (Nishikawa 1974). Previous studies conducted in Otsuchi Bay reported elongation rates of the $U$. pinnatifida thallus on the order of 1-3 cm/day in March (Saitoh et al. 1999; Yoshikawa et al. 2001). Using this elongation rate, the time required for the formation of the top $5 \mathrm{~cm}$ of the pinna (the part examined in this study) is estimated to be on the order of 2-5 days. Therefore, the $\Delta^{14} \mathrm{C}$ of each matured pinna may reflect the $\Delta^{14} \mathrm{C}$-DIC of ambient water integrated over a period of 2-5 days. This time integration of the isotopic signature may contribute to the attenuation (smoothing) of isotopic variability in $U$. pinnatifida relative to the corresponding variability in $\Delta^{14} \mathrm{C}$-DIC.

\section{Conclusion}

We demonstrated that $\Delta^{14} \mathrm{C}$ in $U$. pinnatifida pinnae reflected a shift in exposure from a warm current to the cold Oyashio Current during algal growth. Despite the potential influence of tissue turnover, our data clearly show systematic position-dependent variability in $\Delta^{14} \mathrm{C}$ in $U$. pinnatifida. The large body size and rapid growth of $U$. pinnatifida, which produces a pair of pinnae every 1 or 2 days (Saitoh et al. 1999; Yoshikawa et al. 2001; Gao et al. 2013a), allow us to use its position-dependent variability in $\Delta^{14} \mathrm{C}$ as a unique tool to reconstruct oceanographic conditions experienced by macroalgae during growth. This finding has several important implications for future research. First, determining $\Delta{ }^{14} \mathrm{C}$ could improve the interpretation of variability in other macroalgal isotopic indicators (e.g., $\delta^{13} \mathrm{C}$ as an indicator of algal growth rate, Carvalho et al. 2009; $\delta^{15} \mathrm{~N}$ as an indicator of nitrogen source, Derse et al. 2007), growth measures (thallus length and weight, Yoshikawa et al. 2001), or biochemical indicators (e.g., carbon and nitrogen contents, pigment concentration and composition, Carvalho et al. 2009), facilitating the accurate assessment of relationships between oceanographic conditions and macroalgal physiology. Such information is particularly useful for industrial implications in the Sanriku region, where Oyashio intrusion may seriously affect the growth and physiology of commercially cultivated kelp in a complex manner; e.g., enhancement of productivity (yield) due to the supply of nutrients (a positive effect; Gao et al. 2017) combined with possible discoloration due to low-temperature-induced inhibition of the synthesis of some photosynthetic pigments (a negative effect, as discoloration reduces the commercial value of kelp; Endo et al. 2017). Second, $\Delta{ }^{14} C$ data from macroalgal tissues in preserved samples (e.g., pressed macroalgal samples in museums) could be used to reconstruct past changes in the conditions of oceanic currents. Third, as macroalgal $\Delta^{14} \mathrm{C}$ signatures should transfer to consumers, the $\Delta^{14} \mathrm{C}$ of consumers could be helpful for examining the dependency of the food web on carbon from different ocean current systems. Finally, the ${ }^{14} \mathrm{C}$ approach could be applied to other oceanic regions where aged, upwelled water (depleted in ${ }^{14} \mathrm{C}$ ) is mixed with ${ }^{14} \mathrm{C}$-enriched surface waters (e.g., California upwelling system, Santos et al. 2011), and it provides a new tool to better understand the role of oceanographic conditions in sustaining coastal ecosystem productivity.

Acknowledgements This study was supported by Japan Science Technology Agency CREST grant number JPMJCR13A4, Japan, and the research program "Tohoku Ecosystem-Associated Marine Sciences" of the Ministry of Education, Culture, Sports, Science and Technology. J. Leichter commented on an early draft of the manuscript. H. Takasu, Y. Nishibe, R. Sohrin, and M. Suzuki assisted with field sampling. M. Ishizu and K. Tanaka provided advice on the analysis of physical data. T. Aze assisted with radiocarbon analysis. H. Endoh provided valuable advice on the cultivation of $U$. pinnatifida. We thank the captain and crew of the R/V Shinsei-Maru and the staff of the International Coastal Research Center, Atmosphere and Ocean Research Institute, University of Tokyo, for support during field sampling.

Open Access This article is distributed under the terms of the Creative Commons Attribution 4.0 International License (http://creativeco mmons.org/licenses/by/4.0/), which permits unrestricted use, distribution, and reproduction in any medium, provided you give appropriate credit to the original author(s) and the source, provide a link to the Creative Commons license, and indicate if changes were made.

\section{References}

Ando A, Otobe H, Takagi M (2005) On the river water discharged in Otsuchi Bay. Rep Int Coast Mar Res Cent 30:4-8 (in Japanese)

Carballeira C, Rey-Asensio A, Carballeira A (2014) Interannual changes in $\delta^{15} \mathrm{~N}$ values in Fucus vesiculosus L. Mar Pollut Bull 85:141-145. https://doi.org/10.1016/j.marpolbul.2014.06.010

Carvalho M, Hayashizaki K-I, Ogawa H (2009) Carbon stable isotope discrimination: a possible growth index for the kelp Undaria pinnatifida. Mar Ecol Prog Ser 381:71-82. https://doi.org/10.3354/ meps07948

Derse E, Knee KL, Wankel SD et al (2007) Identifying sources of nitrogen to Hanalei Bay, Kauai, utilizing the nitrogen isotope signature of macroalgae. Environ Sci Technol 41:5217-5223. https://doi. org/10.1021/es0700449

Douka K, Higham TFG, Hedges REM (2010) Radiocarbon dating of shell carbonates: old problems and new solutions. MUNIBE (suplemento Gehigarria) 31:18-27

Endo H, Okumura Y, Sato Y, Agatsuma Y (2017) Interactive effects of nutrient availability, temperature, and irradiance on photosynthetic pigments and color of the brown alga Undaria pinnatifida. 
J Appl Phycol 29:1683-1693. https://doi.org/10.1007/s1081 1-016-1036-8

Endo H, Fukuda H, Takahashi D et al (2018) Influence of isotope fractionation on the nitrogen isotope composition of the brown macroalga Undaria pinnatifida. Phycol Res 66:262-268. https:// doi.org/10.1111/pre.12332

Ferguson JE, Johnson KR, Santos G et al (2013) Investigating $\delta^{13} \mathrm{C}$ and $\Delta^{14} \mathrm{C}$ within Mytilus californianus shells as proxies of upwelling intensity. Geochem Geophys Geosyst 14:1856-1865. https://doi. org/10.1002/ggge.20090

Gao X, Agatsuma Y, Taniguchi K (2013a) Effect of nitrate fertilization of gametophytes of the kelp Undaria pinnatifida on growth and maturation of the sporophytes cultivated in Matsushima Bay, northern Honshu, Japan. Aquac Int 21:53-64. https://doi. org/10.1007/s10499-012-9533-5

Gao X, Endo H, Yamana M et al (2013b) Compensation of the brown alga Undaria pinnatifida (Laminariales; Phaeophyta) after thallus excision under cultivation in Matsushima Bay, northern Japan. J Appl Phycol 25:1171-1178. https://doi.org/10.1007/s1081 1-012-9925-y

Gao X, Endo H, Nagaki M, Agatsuma Y (2017) Interactive effects of nutrient availability and temperature on growth and survival of different size classes of Saccharina japonica (Laminariales, Phaeophyceae). Phycologia 56:253-260. https://doi. org/10.2216/16-91.1

Ge T, Wang X, Zhang J et al (2016) Dissolved inorganic radiocarbon in the northwest Pacific continental margin. Radiocarbon 58:517529. https://doi.org/10.1017/RDC.2016.23

Hanawa M, Mitsudera F (1987) Variation of water system distribution in the Sanriku coastal area. J Oceanogr Soc Jpn 42:435-446

Ishizu M, Itoh S, Tanaka K, Komatsu K (2017) Influence of the Oyashio Current and Tsugaru Warm Current on the circulation and water properties of Otsuchi Bay, Japan. J Oceanogr 73:115131. https://doi.org/10.1007/s10872-016-0383-Z

Key RM (2001) Radiocarbon. Encycl Ocean Sci 75:2338-2353. https ://doi.org/10.1006/rwos.2001.0162

Key RM, Kozyr A, Sabine CL et al (2004) A global ocean carbon climatology: results from Global Data Analysis Project (GLODAP). Glob Biogeochem Cycles 18:1-23. https://doi.org/10.1029/2004G B002247

Kumamoto Y, Murata A, Saito C et al (2002) Bomb radiocarbon invasion into the northwestern North Pacific. Deep Res Part II Top Stud Oceanogr 49:5339-5351. https://doi.org/10.1016/S0967 -0645(02)00194-7

Mann KH (1973) Seaweeds: their productivity and strategy for growth. Science 182:975-981. https://doi.org/10.1126/scien ce. 182.4116 .975

McNichol AP, Aluwihare LI (2007) The power of radiocarbon in biogeochemical studies of the marine carbon cycle: insights from studies of dissolved and particulate organic carbon (DOC and POC). Chem Rev 107:443-466. https://doi.org/10.1021/cr050374g
McNichol AP, Jones GA, Hutton DL et al (1994) The rapid preparation of seawate $\Sigma \mathrm{CO}_{2}$ for radiocarbon analysis at the National Ocean Sciences AMS facility. Radiocarbon 36:237-246. https:// doi.org/10.2458/azu_js_rc.36.1621

Nishikawa H (1974) Studies on the cultivation of Undaria pinnatifida: VI. Growth in each region of the algae bodies. Aquaculture 21:137-142 (in Japanese)

Oguma S, Suzuki T, Nagata Y (2002) Seasonal variations in the sea off Sanriku Coast, Japan. J Oceanogr 58:825-835. https://doi. org/10.1023/A:1022823213855

Otobe $\mathrm{H}$, Onishi $\mathrm{H}$, Inada $\mathrm{M}$ et al (2009) Estimation of water circulation in Otsuchi Bay, Japan inferred from ADCP observation. Coast Mar Sci 33:1-9

Saitoh M, Takeuchi I, Otobe H (1999) Growth of cultivated Unadaria pinnatifida blades in Otsuchi Bay, Iwate, Prefecture. Jpn J Phycol (Sôrui) 47:113-117 (in Japanese)

Santos GM, Ferguson J, Acaylar K et al (2011) $\Delta{ }^{14} \mathrm{C}$ and $\delta^{13} \mathrm{C}$ of seawater DIC as tracers of coastal upwelling: a 5-year time series from Southern California. Radiocarbon 53:669-677. https://doi. org/10.2458/azu_js_rc.53.13066

Shimizu Y, Yasuda I, Ito S (2001) Distribution and circulation of the coastal Oyashio intrusion. J Phys Oceanogr 31:1561-1578. https://doi.org/10.1175/1520-0485(2001)031\%3c1561:DACOT $\mathrm{C} \% 3 \mathrm{e} 2.0 . \mathrm{CO} ; 2$

Stuiver M, Polach H (1977) Discussion; reporting of ${ }^{14} \mathrm{C}$ data. Radiocarbon 19:355-363

Tanaka K, Komatsu K, Itoh S et al (2017) Baroclinic circulation and its high frequency variability in Otsuchi Bay on the Sanriku ria coast, Japan. J Oceanogr 73:25-38. https://doi.org/10.1007/s1087 2-015-0338-9

R Development Core Team (2016) R: a language and environment for statistical computing. R Foundation for Statistical Computing, Vienna. http://www.R-project.org. Accessed 7 Nov 2017 (ISBN 3-900051-07-0)

Wu C, Meng J (1997) Translocation of assimilates in Undaria and its cultivation in China. Hydrobiologia 352:287-293

Yokoyama Y, Miyairi Y, Matsuzaki H, Tsunomori F (2007) Relation between acid dissolution time in the vacuum test tube and time required for graphitization for AMS target preparation. Nucl Instrum Methods Phys Res B 259:330-334. https://doi. org/10.1016/j.nimb.2007.01.176

Yokoyama Y, Miyairi Y, Aze T et al (2019) A single stage Accelerator Mass Spectrometry at the Atmosphere and Ocean Research Institute, The University of Tokyo. Nucl Instrum Methods Phys Res B. https://doi.org/10.1016/j.nimb.2019.01.055

Yoshikawa T, Takeuchi I, Furuya K (2001) Active erosion of Undaria pinnatifida Suringar (Laminariales, Pheophyceae) mass-cultured in Otsuchi Bay in northeastern Japan. J Exp Mar Biol Ecol 266:51-65 